\title{
Study on the Integration of Computer Networks and College English Teaching ZENG Ru-gang ${ }^{1, \text { a }}$ \\ ${ }^{1}$ Zhejiang Agriculture and Business Polytechnic, Shaoxing, P.R. China, 312000, China \\ a ZENGRugang@yeah.net
}

Keywords: Computer Network Technology; English; Curriculum Integration Model

\begin{abstract}
The research for computer network in University and college English curriculum integration has developed rapidly, but the specific research for vocational Public English related is minimal. Aiming at the Higher Vocational English Teaching problems, we take "Basic English + Industry English" course teaching structure, building a new vocational Public English Teaching Mode with computer networks and vocational courses integrated. Studies have proved its effectiveness-being helped to stimulate students' interest in learning English, which will help enhance public vocational English teaching.
\end{abstract}

\section{Introduction}

Students struggling for examinations and English teaching time for university students being too much are the reason of the low English teaching efficiency, which have been a hot topic in the reform of college English teaching. With the expansion of colleges' and universities' area, shortage of teaching resources has become a bottleneck to improve the quality of higher education. Faced with such case, the integration of computer network technology and curriculum, which will achieve efficient integration of limited resources, may be an effective way to solve immediate problems. This paper, as an example, mainly discusses the benefits and any other issues of the integration of computer network technology and college English curriculum model.

In the 21st century, information technology has developed rapidly. The development of computer network technology is the most eye-catching item. it is not only a change of the traditional teaching mode, but also an impact on the traditional teaching philosophy. What's more, it also changed teachers' and students' role and status in the traditional teaching process and is becoming a challenge for our traditional teaching methods and educational system. The shortage of teaching recourses, which is a prominent issue, is caused by college enrollment. Faced with this situation, integrating computer network technology and college English teaching effectively has become the key solution.

\section{Research for the Integration of computer network technology and College English Curriculum}

Entering the new century, the use of computer information network has broken the traditional geographical constraints, becoming an open virtual space which is an information-centric cross-border, cross-cultural and cross-language space. It provides a more convenient condition for college English learning. College English teaching combined with computer network technology is a need of society, which has gradually attracted many scholars' attention.

In 2007, Cai Jing says that from the perspective of teachers and students, computer-based network platform college English teaching mode is a new mode of teaching and the modern trend of education. Computer Assisted Learning helps teachers and students achieve the objective of college English teaching, but there are some problems of this new model. In 2004, Fan Xu suggested that the rapid development of multimedia network technology helps to build an autonomous and personalized English learning mode. She analyzed by comparing the traditional English learning model with multimedia network learning model, and suggested that integrating both of them will be helpful for improving students' English language skills. 


\section{Advantages of the Integration of computer network technology and College English Curriculum}

With the development of technology and society, the computer network has been able to create a viable platform for college multimedia English teaching and provide an opportunity and approach to the reform of traditional teaching mode. Integration of computer network technology and college English curriculum has played an increasingly important role with its own advantages.

\section{a. Help to make students play the main role}

The integration of computer network technology and college English curriculum can help students play the main roles. Students can choose the most suitable class time and use the most appropriate teaching schedule according to their needs and possibilities. They can practice under the guidance of the computer. When faced with difficulties, students can slow down the learning speed, requiring supplementary explanation or increasing the amount of their exercises; when they feel it easy in tests, they can speed up the progress, or reduce the amount of practice after passing the tests. In this process, students can consolidate correct language skills promptly, correct mistakes in the learning progress and format correct language learning habits; students can always call a variety of courseware or materials, or use e-mails and download a variety of information of teaching source online for individualized learning. Learning in this method without interference, students can keep abreast of their own learning condition and maximize their learning initiative.

\section{b. stimulate students' interest in learning}

In addition to the traditional text textbooks, teachers can call a variety of data to edit and product a different courseware which would comply with their teaching style and consistent with the needs of students according to the student's basic situation. What's more, teachers should continuously enrich and update teaching content by online collection and selection of learning materials according to need. Such as reading lessons, teachers can constantly replace the content with new data part without changing the course's requirements of language learning to make the program not only has historical accumulation, but also has characteristics of the times. So it can stimulate students' interest in learning and initiative to achieve to the established teaching purposes, and solve the problems of the less capacity of textbooks and the old content in textbooks. Because of the language of the Internet in English, resources in the form of multimedia online is unaccountable, there are strong current affairs newspaper resources, astronomy, geography, culture, education, entertainment resources. What's more, it has specialized teaching resources. These resources provide authentic information for students without any processing.

\section{c. provide a scientific evaluation standard}

The integration of computer network technology and college English courses provide a scientific evaluation of teaching and learning standards. Using computer networks system of language teaching, teachers can design and develop a variety of scientific testing methods to record and analysis students' acquisition of knowledge and make scientific and reasonable evaluation of the effect of teaching. For example, teachers design self-test questions, special exercises, stage test questions, comprehensive review questions, quizzes and other forms of testing knowledge and practice on the computer first, and then put the answers on the Internet, students can select the test time according to their own learning progress. Teachers can timely adjust to the progress of teaching, teaching content, teaching plans according to the student's answers and information analysis. Students can also use the advantages of multimedia network teaching to select the appropriate learning tasks according to their cognitive characteristics and interests, and can receive timely feedback on their learning at any time. Therefore, computer network technology, as a college English teaching method, provides a fast, timely and accurate feedback information sources for teachers and students to offer an exchange platform for teaching and learning and a scientific evaluation criteria, greatly improving the English teaching methods and promoting the improvement of teaching quality.

\section{Research for the Integration Model of computer network technology and College English Curriculum}




\section{a. The teaching model of the integration of computer network technology and college English curriculum}

From the perspective of information dissemination, teaching is a dynamic two-way process in which teachers use the media information to transmit to the student. Dissemination of computer network technology is not only an information carrier for teachers teaching, but also an access for the students to acquire knowledge. Teachers should use the advantages of computer network technology in teaching progress to develop a practical mode of organic integration of the computer network technology and the college English teaching. Teachers, computer network technology and students should be combined effectively to improve teaching effectiveness and quality.

\section{a) Classroom network teaching mode}

In the integration process, teachers can select a work platform for their preparing lessons, take advantage of a variety of online multimedia teaching resources to adapt their teaching characteristics to produce new courseware. New courseware generally based on templates and multimedia material in repository. This design is simple to learn. Or select an existing courseware in the repository, then put the new courseware into their own teaching resource library.

\section{b) Network collaborative learning model}

In the process of the integration of computer technology and college English curriculum, students can use multimedia computer dormitory, campus network, college English resource library, etc, to discuss for the content, as a group of a dormitory; or be divided into several groups by class randomly.

\section{b. advantages of Integration of Computer network technology and College English Curriculum}

a) Break the limitations of traditional classroom teaching

The integration of Computer network and English teaching is able to change the traditional curriculum situation, because it caused a fundamental change in the framework, and the framework became "teachers - Computer - Textbook - Students" mode. in terms of teaching elements, the relationship between teachers, students, computers and teaching content is not unidirectional, but two-way, multi-directional. In this integration framework of computer and curriculum, the role of teachers has been a fundamental change. They are no longer the teaching center of classroom; students have become active constructors. Thus, in the whole learning process, students may contact the knowledge far beyond the scope of textbooks. There are many ways they can engage in to have meaningful and active knowledge construction.

b) Break the traditional teaching and learning environment

The integration of Computer Networks and college English curriculum will help to break the traditional way of teaching and learning environment to create an ideal learning environment. The creation of an ideal environment thanks to the rapid development of computer network technology.

c) Change the traditional teaching structure

The integration of Computer Networks and college English curriculum can not only create an ideal learning environment, but also make the teaching structure system has undergone a fundamental change. Nowadays, the centre of teaching is no longer the teachers, but the students.

\section{Attention to the problem of integration of computer network technology and college English curriculum}

The integration of computer network technology and college English curriculum has many problems. There are at least four concerns that can be listed as follows. First, teachers should strengthen the guidance of student learning. Second, smooth functioning of hardware and equipment should be ensured. Third, teachers should be encouraged to participate in teaching first-line to design and product educational software. Last but not least, the guidance of network technology should be strengthened. 


\section{References}

[1] Adams, S. \& Burns, M. (1999). Connecting Student Learning \& Technology. Retrieved 28Septempber,2003, from http://www. sedl. org/pubs/tec26 /flash. html.

[2] Baba, H. (2000). Multimedia pendidikan dalam P \& P Selolah Bestari. Jurnal BTP (2) ,77-85.

[3] Hutchinson T. \& Waters A. , 1987, English forSpecific Purposes-Learning-centered Approach [M].Cambridge: Cambridge University Press.

[4] Kasper, L. F. (2000). New technologies, new literacies:Focus discipline research and ESL learning communities.Language Learning \& Technology, 4 (2), 109- 128 (Retrieve from http://ltt. Msu. Edu /vo1104num102/kasper/default. html).

[5] Muir-Herzig, R. G. (2004). Tecnology and itsimpact in the classroom. Computers \& Education, $42(2), 111-131$. 